\title{
Metabolik gıda intoleransları
}

\section{Metabolic food intolerances}

\author{
Aylin AKOĞLU ${ }^{1 *}$ iD , Murat ORUç iD \\ ${ }^{1}$ Abant İzzet Baysal Üniversitesi Bolu Sağlık Yüksekokulu, Beslenme ve Diyetetik Bölümü, Bolu \\ ${ }^{2}$ Abant İzzet Baysal Üniversitesi ARGE Vakfı, Gölköy Bolu
}

\section{To cite this article:}

Akoğlu, A., Oruç, M., 2018. Metabolik gıda intoleransları. Harran Tarım ve Gıda Bilimleri Dergisi, 22(2): 284295

\section{Address for Correspondence:} Aylin AKOĞLU

e-mail:

aylinakoglu@ibu.edu.tr

Received Date:

07.03.2017

Accepted Date:

24.11.2017
(C) Copyright 2018 by Harran University Faculty of Agriculture. Available on-line at www.dergipark.gov.tr/harranziraat

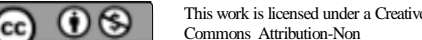
Commons Attribution-Non Commercial 4.0 International Licens

Giriş

Gıda alımını takiben bazı istenmeyen reaksiyonların oluştuğu ilk kez M.Ö. 100 yılında

\section{öz}

Gıda intoleransı, bir gıda maddesinin vücutta sindirilememesinden veya emilememesinden ileri gelen, genellikle gıda alerjisi ile karıştıılan ancak gıda alerjisine göre daha yaygın görülen bir rahatsızlık türüdür. Gıda intoleransının neden olduğu semptomlar, gıda alerjisi semptomlarına benzemekte, gastrointestinal, kutanöz ve solunum hastalıklarını içermektedir. Ancak her iki rahatsızlık farklı mekanizmalarla gerçekleştiğinden tedaviler farklııı göstermektedir. Gıda intoleransları enzimatik, farmakolojik ve tanımlanamayan gıda intoleransları olmak üzere üçe ayrılmaktadır. Enzimatik gıda intoleransı; besin öğelerinin vücutta kullanılmasında görev alan enzimlerden birinin, genlerdeki hata sebebiyle yeterli sentezlenemeyişi ya da hiç sentezlenememesinden dolayı meydana gelen ve metabolik gıda intoleransı olarak adlandırılan bir durumdur. Dünya genelinde gıda intoleransı tanısı konulmuş insan sayısının oldukça fazla olması ve konu hakkında insanların yeterli bilgiye sahip olmayışı konunun ne derece önemli olduğunun bir göstergesidir. Bu çalışma, metabolik gıda intoleranslarından olan laktoz intoleransı, çölyak, fenilketonüri, galaktozemi, früktoz intoleransı ve favizm hakkında genel bir bilgi vermek amacıyla hazırlanmıştır.

Anahtar Kelimeler: Gıda Alerjisi, Gıda intoleransı, Enzim, Çölyak, Laktoz

\section{ABSTRACT}

Food intolerance is a type of discomfort that is more common with food allergies, but with a higher incidence than food allergies, resulting from the inability or inability to digest a food substance in the body. Symptoms caused by food intolerance are similar to symptoms of food allergy, including gastrointestinal, cutaneous and respiratory diseases. However, the treatments differ because both disorders occur with different mechanisms. Food intolerances are divided into three, which are enzymatic, pharmacological and unidentified food intolerances. Enzymatic food intolerance is a condition called metabolic food intolerance that occurs because of insufficient synthesis or no synthesis of one of the enzymes involved in the use of nutrients in the body due to errors in the genes. The number of people diagnosed with food intolerance and people's not having enough information about the subject is an indication of how important the subject is. This study was designed to give general information about lactose intolerance, celiac, phenylketonuria, galactosemia, fructose intolerance and favicism from metabolic food intolerances.

Key Words: Food Allergy, Food intolerance, Enzyme, Celiac, Lactose

Lucretus tarafından tanımlanmıştır. Gıdalara karşı oluşan ters reaksiyon, gıdanın alımından sonra ortaya çıkan herhangi bir anormal reaksiyondur (Bayrak, 2006). Bu reaksiyonlar, patolojik 
mekanizmalarına göre sınıflandırıldıklarında toksik ve toksik olmayan reaksiyonlar olmak üzere ikiye ayrılır. Toksik gıda reaksiyonlarının semptomları, toksik olmayan reaksiyonun semptomlarından ayırt edilebilmektedir. Ayrıca toksik gıda reaksiyonları gıdayı tüketen tüm bireylerin metabolizmalarında etkili olurken, toksik olmayan reaksiyonlar yalnızca o gıdaya duyarlılığı olan bireyleri etkilemektedir. Toksik olmayan reaksiyonlar da kendi içinde ikiye ayrılmaktadır. Bunlar, bağışıklık sistemi ile ilişkili olan ve bağışıklık sisteminden bağımsız olan reaksiyonlardır. Gıda alerjisi terimi yalnızca bağışıklık sistemi ile ilişkili olan reaksiyonlar için kullanılırken, bağışıklık sisteminden bağımsız olan ters reaksiyonlar gıda intoleransı olarak adlandırılmaktadır. Gıda alerjileri kendi içinde IgE (İmmünglobulin E) kaynaklı olanlar ve IgE kaynaklı olmayanlar olmak üzere 2 grup altında incelenir. Gıda intoleransları ise enzimatik, farmakolojik ve tanımlanamayan gıda intoleransları olmak üzere üçe ayrılmaktadır (Bruijnzeel-Koomen ve ark., 1995; Ispano ve ark., 1998; Johansson ve ark., 2001; Ortolani ve Pastorella, 2006).

Günümüzde gıda kaynaklı sağlık problemlerinin birçoğu gıda alerjilerinden ve intoleranslarından kaynaklanmaktadır. Gluten içeren tahıllar, laktoz içeren süt ve süt ürünleri, balık, kabuklu deniz ürünleri, yumurta, yer fıstığı, soya, fındık, ceviz, susam tohumu, meyve ve sebzeler, baklagiller, baharatlar ve lezzet arttırıcılar bu problemlere neden olan bazı gıdalardır (Özer ve Tuncel, 2016). Çocuklarda, inek sütü, yumurta, yer fıstığı ve soya fasulyesi, en yaygın alerji ve intolerans oluşturan besinler olarak belirlenmiş olmasına rağmen, yetişkinlerde benzer veriler daha azdır ve doğrulanmasına gerek duyulmaktadır (Gübür, 2012).

Gıda intolerasları gıda alerjilerine kıyasla daha az tanımlanmıştır ve tanıları alerjilere oranla daha karmaşıktır. En sık rastlanan gıda intoleranslarının başında gelen laktoz intoleransının tanısı nefes testi ile kesin bir şekilde yapılabilmekteyken, diğer gıda intoleranslarının tanısını net bir şekilde koymak güçtür (Ortolani, 2006). Gıda alerjisi tanısında kullanılan deri veya kan testi uygulamaları gıda intoleransı tanısı için uygun değildir (Gübür, 2012). Bunun yanında, gıda alerjilerinde özellikle gastrointestinal bölgede gerçekleşen değişiklikleri ve oluşan semptomları izlemek amacıyla en çok kullanılan metotlardan biri olan yüksek frekanslı intraluminal ultrasonografi cihazıyla görüntüleme tekniği, gıda intoleranslarını saptamak amacıyla da kullanılabilmektedir. Bu cihaz sayesinde gastrointestinal bölge duvarının tabakaları detaylı bir şekilde incelenebilmektedir. Böylece bu metod ile belli gıdalara karşı duyarlılığı olan kişilerde gastrointestinal bölge duvarının kalınlığı ve intolerans ile gerçekleşen mukozal değişiklikler izlenebilmektedir (Menzel ve ark., 2000; Arslan ve ark., 2002). Diğer bir tanı yöntemi ise şüpheli gıdaların diyetten çıkarılması ve metabolizmadaki değişikliklerin izlenmesi yöntemidir (Ferguson, 1992).

Gıda intoleransının neden olduğu semptomlar gastrointestinal, kutanöz, ve solunum hastalıklarını içeren gıda alerjisi semptomlarına benzerlik göstermektedir. Bu nedenle, farklı gıda alerjisi tanısında gıda intoleransını göz önünde bulundurmak gerekir (Gübür, 2012). Gıda intolerasında rahatsızlık süresince görülen semptomların çeşidi, özelliği ve zamanla bu semptomlarda ne gibi değişiklikler olduğu, intoleransı tetikleyen başka gıdaların ya da hastalıkların olup olmaması tanının konulmasında önemli rol oynamaktadır. Bireylerin sağlık durumları, yaşı ve farklı beslenme alışkanları, gıda intoleranslarının ortaya çıkmasında genetik özellikler kadar olmasa da tanıda göz önünde bulundurulan faktörlerdir. Genel semptomlar tek başlarına gözükebilecekleri gibi, bir veya daha fazla organı etkileyen çeşitli semptomların genel bir kombinasyonu halinde de görülebilmektedir. En sık görülen gıda intoleransı semptomları, karın ağrısı, diyare, mide bulantısı, kusma, şişkinlik, hazımsızlık, burunda akıntı, baş ağrısı ve kurdeşandır (Vatn, 1997). Reaksiyona neden olan besinler tüketilmeye devam edildikçe kişilerin sağıkları olumsuz etkilenebilmektedir (Gübür, 2012).

Gıda intoleransı semptomları gıda alerjisi ile 
benzer olmasına rağmen tedavi yöntemleri farklılık göstermektedir. Gıda intoleranslarının bilinen herhangi bir tedavisi olmamakla birlikte intolerant bireylerin intolerans gösterdikleri maddeyi içeren gıdaları diyetlerinden çıkarmaları gerekmektedir (Vatn, 1997). Bu durumda intolerans oluşturan besin, belirli bir süre diyetten çıkarılırsa semptomlarda azalma görülmekte ve aylar sonra intolerans oluşturan besine karşı reaksiyon gözlenmemektedir. Eğer intoleransa neden olan besini tüketmeye her gün devam edilirse, intolerans bir ay içerisinde bile tekrar ortaya çıkabilir. Bazen de gıda intoleransı nedeniyle oluşan reaksiyonlar, intoleransa neden olan besinin elimine edilmesiyle hemen kaybolabilir ve hasta normal diyetine geri dönmesine rağmen, reaksiyon tekrar oluşmayabilir. Bu durum çocuklarda daha sık yaşanır (Gübür, 2012).

$\mathrm{Bu}$ çalışma, söz konusu rahatsızlıklara farkındalığı artırarak hastalığın erken tanısına katkıda bulunmak ve intolerant bireylere hastalık konusunda bilgi vermek amacıyla hazırlanmıştır.

\section{Metabolik gıda intoleransları}

Herhangi bir enzimatik eksiklikten kaynaklanan gıda intoleransları metabolik gıda intoleransı olarak bilinmektedir. Metabolizmada, besin öğelerinin sindirimi, emilimi, hücrelere taşınması, çeşitli maddelerin değişikliğe uğraması ve vücuttan atılması gibi olaylarda birçok enzim görev almaktadır. Metabolik gıda intoleransı, besin öğelerinin vücutta kullanılmasında görev alan enzimlerden birinin, genlerdeki hata sebebiyle yeterli sentezlenemeyişi ya da hiç sentezlenememesinden dolayı meydana gelebilmektedir. Bunun yanında intolerans, kromozomlar üzerinde bulunan genlerdeki bozukluktan da ileri gelebilir. Bazen hastalık geni bulunanlarda hastalık önemli bir belirti vermeyebilir fakat çocuklarında şiddetli olarak ortaya çıkabilir. Vücutta kullanılamayan maddenin birikimi toksik etki gösterebilmekte ya da enzimler aracılığı ile ondan yapılacak olan maddenin eksikliği görülebilmektedir (Anonim, 2008).
En
yaygın
görülen
metabolik
gida

intoleransları; laktoz intoleransı, çölyak, fenilketonüri, galaktozemi, früktoz intoleransı ve favizimdir. Aşağıda, sırasıyla bu intoleransların her birinin nasıl oluştuğu, hangi gıdaların risk grubunu oluşturduğu ve söz konusu gıdalar tüketildiğinde hangi semptomların ortaya çıktığı hakkında bilgi verilmiş ve tanı ile tedavi yöntemlerine kısaca değinilmiştir.

\section{Laktoz intoleransı}

Laktoz intoleransı, metabolizmada laktozu, glukoz ve galaktoza parçalayan laktaz enziminin eksikliğinde meydana gelmektedir (Ray, 1996; Fadıloğlu ve Erkmen, 2004). Bu enzim kalıtsal nedenlerden ötürü doğuştan eksik olabileceği gibi, genlerde sonradan meydana gelen mutasyonlardan ötürü de sentezlenemeyebilir (Fox, 1997a). Laktaz enzimi eksikliğinde laktozun tolere edilememekte ve kalın bağırsakta mikroorganizmalar tarafından fermantasyona uğratılarak laktik asit, kısa zincirli yağ asitleri, karbondioksit ve hidrojen gazları ile bazı durumlarda metan gazı üretilmesine sebebiyet vermektedir. Bu durum, gaz, şişkinlik, diyare, karın ağrı ve krampları gibi rahatsızlıklara yola açmakta ve bu semptomlar, laktoz intoleransının bir işareti olarak görülmektedir (Fox, 1997a; Harju, 2000). Ayrıca laktoz intoleranslı çocuklarda su kaybı ve elektrolit düzensizlikleri ile sonuçlanan daha ağır durumlarda meydana gelebilmektedir (Wilson, 2005).

Bebeklerde malabsorpsiyon (emilim bozukluğu), kalıtsal olduğu durumlarda süt emme başlangıcı ile belirgin hale gelir ve intolerans sulu ve köpüklü gaita ile kendini gösterir. Süt ve süt ürünleri kesildiği zaman malabsorpsiyonda kendiliğinden düzelir. Yetişkinlerde ise laktoz intoleransı, kalıtsal veya genlerde sonradan ortaya çıkan bir değişikle oluşabileceği gibi, gastrointestinal kanalın viral ve bakteriyel enfeksiyonları ve diğer bağırsak sendromları sırasında da gözükebilmektedir (Patıroğlu, 1994). Yapılan bir çalışmada, bağırsak sendromu geçiren ve süte karşı intolerans gösterdiğini iddia eden iki grubun klinik tanısında hemen hemen aynı sonuçlara ulaşılmıştır. Bağırsaklarda absorbe 
edilemeyen

laktozun

fermantasyonu, semptomların başlamasını tetiklediği için, bağırsak sendromunun tanısında da tıpkı laktoz intoleransında olduğu gibi hidrojen testi uygulanması önerilmektedir (Vernia ve ark., 2001).

Laktoz intoleransının tanısında kullanılan ilk yöntem intestinal biyopsi ile doğrudan laktaz enziminin eksikliğinin tespit edilmesidir (Dahlqvist ve ark., 1963). Fakat bu yöntem büyük ölçekli çalışmalar için kullanışlı olmadığından alternatif yöntemlere ihtiyaç duyulmuştur. Zamanla kan glukoz testi ve hidrojen testi kullanılmaya başlanmıştır (Levitt ve Donaldson, 1970). Bu testlerden glukoz testi, laktoz hidrolizi ile ortaya çıkan glukozun kana hızlı bir şekilde absorbe olması temeline dayanmaktadır. Laktoz intoleranslı bireylerde laktoz parçalanamadığı için kandaki glukoz konsantrasyon değeri daha düşük çıkmaktadır. Solunum sistemindeki hidrojen konsantrasyonun ölçüldüğü hidrojen testi glukoz testine göre daha fazla tercih edilmektedir. Bu yöntemin esası ise, laktaz enzimi eksikliğinde hidrolize olamayan laktozun kalın bağırsaklarda bakteriler tarafından fermantasyona uğratılmasıyla açığa çıkan hidrojen gazı konsantrasyonun ölçülmesine dayanmaktadır (Fox, 1997a).

Laktoz intolerant bireylerin, süt, peynir, dondurma, krema, tereyağı, süttozu, peynir altı suyu ve tozu gibi süt ürünleri ve bunların herhangi birinin bileşen veya katkı maddesi olarak içine ilave edildiği gıdaları diyetlerinden çıkarmaları gerekmektedir. Yoğurt, ayran, kefir gibi fermente süt ürünleri ile prosesinde kültür kullanılan bazı peynirlerde laktoz, starter mikroorganizmalar tarafından fermantasyon prosesi boyunca parçalanmaktadır. Bu nedenle fermente süt ürünleri, laktoz intolerant bireyler tarafından süte kıyasla daha az risk taşımaktadır. Ancak bu tip ürünlerde laktoz tamamen hidrolize olmadığında ve bunun yanısıra, kişide laktozun, belirtileri ortaya çıkarabilecek etkili dozunun tespitinin zor olması sebebiyle hastalar bu konuda uyarılmalıdır ve çoğu zaman bu riski de göze almaktan kaçınılmalıdır. Bu ürünlere alternatif olabilecek laktozu hidrolize edilmiş süt ve süt ürünleri tercih edilmelidir. Bu nedenle laktozun hidrolizasyonu, yapılarında hiç laktoz bulunmayan yeni ürünlerin geliştirilmesi için gıda endüstrisinde oldukça teşvik edilen bir yöntemdir. Günümüzde laktozu tamamen hidrolize edilmiş süt, yoğurt, peynir ve dondurma gibi pek çok ticari ürün piyasada yerini almıştır. Ayrıca tüketicilerin evlerinde rahatça kullanabilecekleri, ticari laktaz enzimi preparatları piyasadan temin edilebilmektedir. Bu durum, dünya nüfusunun büyük bir kısmının (yaklaşık \%70'inin) maruz kaldığı laktoz intoleransının çözümü için oldukça önem arz etmektedir (Fox, 1997b; McBean ve Miller, 1998; Tarakçı ve Küçüköner, 2005; Özer, 2006; Tonguç, 2012).

Laktozun tek kaynağının süt ve sütten yapılan gıdalar olduğu düşünülse de, sıklıkla hazır gıdalara katkı maddesi olarak eklendiğinden, aynı zamanda içeriğinde laktoz dolgu maddesi bulunan ilaçların da piyasada olması nedeniyle tüketicilerin bu konuda dikkatli olması gerekmektedir. Aynı zamanda süt ürünü olarak tanımlanmayan, kahve kreması tozu, çeşitli pasta süsleme sosları, sütten elde edilen besin maddelerinin türetilmesiyle üretildiklerinden dolayı belli bir miktar laktoz içermeleri olasıdır. Bu nenenle etiket bilgileri dikkatlice okunmalı ve tüketiciler bu konuda bilinçlendirilmelidirler. Diğer taraftan çikolatalı süt, yağsız süt ve dondurma gibi katkı maddeleri ilave edilmiş veya işlenmiş sütlerin ve özellikle, canlı mikroorganizma içeren yoğurtların, bakteriler tarafından salgılanan laktaz enzimi de içermeleri nedeniyle hastalar tarafından daha iyi tolere edilebildiği ifade edilmiştir. Ayrıca soya sütü ve pirinç sütü gibi süt içermeyen ikame içecekler de iyi tolere edilebilen gıdalar arasında yer almaktadır (Tonguç, 2012).

\section{Çölyak}

Bağışıklık sisteminin, diyet ile buğday, arpa, yulaf ve çavdardan alınan gluten proteinlerine gösterdiği reaksiyon sonucunda ortaya çıkan bir ince bağırsak bozukluğudur. Kısaca gluten proteinlerinin sindirilememesi olayıdır. Gıda alerjisi değildir; ancak vücudun kendi bağışıklık sistemine zarar vermesinden dolayı otoimmun bir 
hastalıktır. Gıda alerjisi reaksiyonlarında antikorlar rol oynarken, çölyak hastalığında bağırsak çeperi antikorlar tarafından değil, bağışıklık sistemindeki akyuvar hücreleri (T-lenfositler) tarafından hasara uğratılır (Artan, 2005; Akarslan ve ark., 2007).

Hastalık ilk olarak 1888 yılında Samuel Gee tarafından tanımlanmış ve 1950 yılında Dicke hastalığın patogenezinde buğday ve çavdarda bulunan gluten isimli proteinin rolü olduğunu göstermiştir (Hill ve ark., 2002). Günümüzde insanoğlunda en sık rastlanan genetik hastalık olarak kabul edilmektedir. Çölyak hastalığı diğer bir adıyla gluten intoleransı dünya nüfusunun \%12'sini etkilemektedir (Aydoğdu ve Tümgör, 2005). Klinik testlerle elde edilen tarama çalışmaları, çölyak hastalığının sıklığının tüm dünyada giderek artan bir eğilimde olduğunu göstermektedir (Dalgic ve ark., 2011). Son yıllarda yapılan epidemiyolojik çalışmalarda çölyak hastalığının dünyanın birçok ülkesinde benzer oranlarda görüldüğü (Avrupa ülkeleri, Rusya, Kuzey ve Güney Amerika, Akdeniz ülkeleri, Güney Afrika, Hindistan, İran, Sahra Afrika'sı, Avustralya ve Yeni Zelanda) dikkatleri çekmektedir. Halen Pasifik Adaları, Japonya, güney doğu Asya ve doğu Çin hastalığın nadir görüldüğü ülkeler arasındadır. Bu bölgelerde beslenme alışkanlıklarının henüz batı tarzı yeme-içme alışkanlıklarına benzememiş olmaması bu durumun nedeni olarak düşünülmektedir (Cummins ve Roberts Thomson, 2009). Türkiye' de tahmin edilen çölyaklı sayısı 700.000, tanısı konmuş çölyaklı sayısı 10.000 olarak bildirilmiştir (Dede, 2016).

Çölyak hastalığı, özellikle çok küçük ve parmak şekline benzeyen villus olarak adlandırılan ince bağırsaktaki emilimi sağlayan yapıların kaybolmasıyla ortaya çıkmaktadır. Villuslar düzleşmekte ve görevini yapamaz hale gelmektedir (Patıroğlu, 1994; Akarslan ve ark., 2007; Özer ve Tuncel 2016). En belirgin semptomları mide bulantısı, gaz, yorgunluk, kabızlık, büyümede yavaşlama ve ciltte sorunlar olmasına rağmen semptomlar ölüme kadar giden geniş bir yelpazede kendini göstermektedir (Aydoğdu ve ark., 2005). Beyaz ırkta özellikle çocukluk çağında görülme sıklığı, son verilere göre
$1 / 300$ ve $1 / 80$ arasında değişmektedir (Hill ve ark., 2005). Çölyak patogenezinde kalıtsal, çevresel ve immunolojik faktörler rol oynamasına rağmen, bunlar içinde en önemli olanı kalıtsal faktörlerdir. Yapılan çalışmalarda aynı aileden birden fazla kişinin bu rahatsızlığı yaşadığını göstermektedir. Çalışmalarda hastaların birinci derece akrabalarında \%10-12 oranında çölyak rahatsızlığına rastlandığı saptanmıştır (Ascher, 1996; Book ve ark., 2003; Högberg ve ark., 2003). Ayrıca hastalık doğuştan olabildiği gibi çocukluk, ergenlik, orta yaş gibi yaşamın farklı evrelerinde de ortaya çıkabilmekte aynı zamanda ameliyat, hamilelik, doğum, viral enfeksiyon ya da şiddetli duygusal stres gibi faktörler de hastalığı tetikleyebilmektedir (Anonim, 2017).

Çölyak hastalığının kesin tanısı ancak deneyimli bir gastroenterolog tarafından yapılacak kan tahlilleri ve ince bağırsak biyopsisi ile konulabilmektedir. Son zamanlarda ise ELISA testi çölyak rahatsızlığının tespitinde sıklıkla kullanılmaktadır. Günümüzde çölyak hastalığının kesin tedavisi ömür boyu süren glutensiz diyet uygulamasıdır. Biyopsi yapılmadan asla glutensiz diyet başlatılmamalıdır (Aydoğdu ve Tümgör, 2005). Çölyak hastası kişiler normal ekmek, makarna, pasta, börek, bisküvi ve benzeri çok sayıda gıdayı tüketememekte bunların yerine gluten içermeyen mısır unu, pirinç unu, soya unu, patates unu ve bunlardan yapılmış gıdaları rahatlıkla tüketebilmektedirler (Özer ve Tuncel, 2016). Çölyak hastaları için izin verilen tahıllar; karabuğday, mısır, kinoa, pirinç, patates, kestane, amaranth (Meksika ve Orta Amerika'da çok bulunur), yasaklı tahıllar ise buğday, bulgur, kuskus, çavdar, arpa, kabuklu buğday ve yulafır. Geçmişte çölyak hastaları için toksik olduğu düşünülen yulafın son çalışmalarda güvenli olmasının yanında diyet kalitesini de arttırdığı gösterilmiştir (Dede, 2016).

Çölyak hastalığında tanı, sıkı glutensiz diyete uyum sonrası yakınmaların kaybolması ile kesinleşir. Sıkı glutensiz diyet sonrası serolojik testlerin negatifleşmesi de tanıyı doğrulayan diğer önemli bir kriterdir. Bu özelliklere sahip hastalarda ikinci bir biyopsiye gerek 
görülmemektedir (Aydoğdu ve Tümgör, 2005).

Çölyak hastalığının önlenmesi amaçlı bazı tıbbi yöntemler uygulanmaktadır. Bu yöntemlerden birinde gluten peptitlerinin ince bağırsağa göçünü azaltmak ve emilmeden atılımını sağlamak için paraselüllar geçirgenliği azaltan inhibitör maddeler kullanılmaktadır. Diğer bir yöntemde ise doku transglutaminaz inhibitörleri, DQ2 veya DQ8 blokörleri kullanılarak bu polimerle gluten bağlanmakta ve sindirime uğramadan atılması sağlanmaktadır (Tennyson ve ark., 2009).

Birçok araştırıcı çölyak hastalarının tüketimine yönelik ürün formülasyonu geliştirme yönünde çalışmalar yapmışlardır. Bu çalışmalarda gluten içeren tahıllardan elde edilmiş unlar yerine, pirinç unu, hardal unu, misır unu, soya unu, kestane unu, nohut unu, patates unu gibi çeşitli unlar ve kombinasyonları kullanılarak ekmek, erişte, bisküvi gibi farklı ürünler üretilmiş ve bu ürünlerin kimyasal, mikrobiyolojik ve duyusal analizleri yapılarak kalite özellikleri ile genel beğeni durumları ortaya konulmaya çalışılmıştır (Schober ve ark., 2003; Gambus ve ark., 2009; Mezaize ve ark., 2009; Demirkesen ve ark., 2010; Torbica ve ark., 2010; Ergin, 2011). Bu çalışmalara paralel olarak çölyak hastaları düşünülerek hazırlanan ve ticari üretimi olan glutensiz ekmek, makarna, bisküvi, kraker, kek, cips gibi pek çok ürün piyasada yer almaktadır.

Glutensiz yeni ürün formülasyonlarının ortaya çıkarılması üzerine de pek çok çalışma yapılmaktadır. Bu çalışmalarda gluten proteinin yapısı değiştirilerek, glutenin antikorlar tarafından fark edilmesini önlemek prensibi öne çıkmaktadır. Böylece, güvenilir ve vücut tarafından sindirilebilir bir ürün üretmek amaçlanmaktadır. Ekşi ekmekte uzun dönem fermantasyon ve enzimatik modifikasyonla bu amaca ulaşılmış ve çölyak hastalarının rahatlıkla tüketebileceği ekmek üretilmiştir (Gallagher, 2008; Moroni ve ark., 2009; Cabrera-Chávez ve ark., 2010).

Endüstriyel anlamda üretimlerde; üretim esnasında kontaminasyon riski, korunmanın pahalılığı ve ayrı bir ekipman ihtiyacı, görece az sayıda kişiye ulaşım/kısıtlı tüketim alanı, ürün geliştirme konusundaki kısıtlılıklar/dar ürün gamı gibi teknik zorluklar yaşansa da glutensiz ürün yelpazesi gün geçtikçe artmaya devam etmektedir (Dede, 2016).

\section{Fenilketonüri}

Bu rahatsızlık, laktoz intoleransı ve çölyak hastalığına oranla daha nadir görülen kalıtsal metabolik bir hastalıktır. Rahatsızlık, metabolizmada fenilalanin aminosidini tirozine dönüştüren fenilalanin hidroksilaz enziminin eksikliği olduğu durumda ortaya çıkmaktadır (Cunningham ve ark., 1969). Anne baba da rahatsızıı gözükmese bile, her ikisi de taşıyıcı olan bir çiftin her bir çocuğunda görülme ihtimali \%25'tir. Amerika'da birçok Avrupa ülkesinde fenilketonüri hastalığı 10.000-30.000 bebekte bir görülmesine karşılık, ülkemizde 3.000-4.000 bebekte bir görülmektedir. Hastalığın dünyada görülme sıklığının en yüksek olduğu ülke, akraba evliliklerinden dolayı Türkiye'dir ve ülkemizde her yıl ortalama 300-400 yeni fenilketonürili bebek doğmaktadır. Diğer taraftan akraba evliliği hastalığın görülme sıklığını artırıyor olsa da, akraba olmayan bireylerin de çocuklarının hastalıklı doğabileceği bildirilmektedir. Ülkemizde her 100 kişiden 4'ünün bu hastalığın taşıyıcısı olduğu bilinmektedir (Altunsu, 2007; Soysal, 2010; Ergül, 2011).

Bu hastalığa sahip olan bebeklerde doğumdan sonra normal bebeklerden bir farklılık söz konusu değildir. Fakat proteinli gıdalarla alınan fenilalanin aminoasidi sindirilemediğinde, kanda ve diğer vücut sıvılarında biriken fenilalanin ve artıkları sinir sisteminde zehir etkisi göstermeye başlar (Matalon ve Michals, 1991). Illk aylardan sonra hastalığın gelişim derecesine göre zeka geriliği başlamaktadır. Hastalık, bebeklikten çocukluğa geçiş çağında da beyne önemli zararlar vermekte ve çocuğun ileri derecede zeka özürlü olmasına yola açmaktadır. Vakaların bir kısmında sıçrama şeklinde tarif ettiğimiz, kısa süreli ani kasılma nöbetleri vardır. Başları normal ölçülere göre küçüktür. Kol ve bacaklar sert, sürekli kasılmış halde gibidir. Anne-baba ve hastalıktan etkilenmemiş kardeşlere kıyasla, bu çocuklar daha açık renklidir, sarışın, ince telli saçlı ve mavi gözlü 
olurlar. Bunun nedeni fenilalaninin bedenin renk maddesi olan melanini yapmakla yükümlü tirozine dönüşemediğinden dokularda tirozin eksikliği gözükmesidir. Vakaların üçte bir kadarında egzama türü kaşıntılı deri döküntüleri vardır. Büyük çocuklarda hiperaktivite, kendine zarar verme atakları, ritmik sallanma, otizme benzer dıştan kopuk davranış sıktır. Yaklaşık dörtte bir vakada sara nöbetleri yerleşir. Zeka geriliği ve nörolojik bulgular yaş ilerledikçe artar. Aynı hastalığı taşıyan kişiler arasında hastalığın klinik bulguları çeşitlilik gösterir. Bir ailede kardeşlerden birinde bulgular çok ağır olabilirken, diğer kardeşte çok daha hafif olabilmektedir (Soysal, 2010).

Fenilketonüri hastalığının genetik olarak tanısı yapılabilmekte ve hatta doğum öncesi plasentadan alınan örneklerden bebeğin hastalık taşıyıp taşımadığı saptanabilmektedir. Bu şekilde erken tanı konularak uygun diyet programı takip edilen çocukların sağlıklı gelişimleri mümkün olmaktadır (Hanley ve ark., 1999; Soysal, 2010; Spronsen ve Enns, 2010).

Hastalığın tedavisinde ömür boyu sürdürülmesi gereken bir diyet söz konusudur ve çok sıkı takip edilen diyet uygulaması ile klinik belirtiler ortaya çıkmadan hastanın sağlıklı bir yaşam sürmesi mümkündür. Beyin hasarını önlemek için vücuttaki fenilalanin düzeyini azaltmak tedavinin temel amacıdır. Fenilalanin vücut için çok önemli bir yapı taşı olduğundan, hastalığın ağırlığı elverdiği ölçüde diyetteki doğal protein ile fenilalanin alımına izin verilir. Hastanın normal büyümesini devam ettirebilmek için gerekli ek günlük protein ise, yapay olarak hazırlanmış ve fenilalanin içermeyen özgün endüstriyel besinlerle sağlanır. Özel diyet tedavisinde geç kalınırsa çocukta kalıcı zihinsel gerilik oluşabilir (Baysal, 1992). Fenilketonürili hastaların diyet tedavisinde, diyetin protein, enerji, vitamin, mineral ve fenilalanin açısından yeterli ve dengeli olması gerekir. Bu yüzden fenilketonürili hasta ve yakınları tarafından diyet tedavisinde tüketimi serbest gıdaların, tüketilmemesi gereken gıdaların, sınırlı miktarda tüketilecek gıdaların (tartılarak verilen gıdalar) ve düşük fenilalanin içeren medikal ürünlerin bilinmesi gerekir (Özer ve ark., 2008). Et (et ürünleri, sakatat, balık, kabuklu deniz ürünleri, beyaz et vb. ), yumurta, süt ve süt ürünleri, kuruyemiş, baklagiller gibi yüksek proteinli gıdalara diyette yer verilmemekte bunun yerine fenilalanin içeriği düşük olan sebze ve meyvelerin kontrollü tüketimi önerilmektedir (Seçkin, 2007). Bu hastalarda yeterli protein alınmadığından ve alınan proteinin kaynağı sebze ve meyveler olduğundan büyüme ve gelişme problemleri ortaya çıkmaktadır (Özer ve ark., 2008).

Fenilketonüri hastalarının diğer metabolizma hastalıklarından (çölyak, galaktozemi vb.) en önemli farkı tüketebilecekleri gıda çeşidinin çok az olmasıdır. Buna paralel olarak mevcut ürünlerin çoğunun ithal ürün olması hem ailelere hem de devlete mali bir yük getirmektedir (Ergül, 2011). Fenilketonürili hastaları için hazırlanmış ve ticari olarak tüketilen ürünler mevcuttur ve bunun yanısıra yeni ürün geliştirme yönünde laboratuvar ölçekli çalışmalar da yapılmaktadır. Kılıç ve ark. (2008) yaptıkları çalışmada kaşar peynirine benzer dokusal ve duyusal özelliklere sahip, fenilalanin içeriği yaklaşık olarak on kat azaltılmış peynir jeli oluşturmuş ve fenilketonüri hastalarının beğenisine sunmuştur. Duyusal değerlendirme sonucunda hastaların büyük bir çoğunluğunun ürünü beğendiğini ve iki ürün arasındaki farkı algılayamadıklarını tespit etmiştir. Benzer bir çalışma Ergül (2011) tarafından yapılmış, peynir altı suyundan izole edilmiş KMP (kazeinomakropeptit) kullanılarak enerji değeri ve besin içeriği açısından fenilketonüri hastalarının diyetinde yer alabilecek düzeyde fenilalanin içeren meyveli puding üretimi gerçekleştirilmiş ve kimyasal ve duyusal analizleri yapılmıştır. Duyusal özellikler açısından en beğenilen formülasyon, \% 15 oranında $\mathrm{KMP}_{120 \mathrm{~B}}$ izolatı ve \% 15 oranında liyofilize maviyemiş içeren puding olmuştur.

\section{Galaktozemi}

Galaktozemi, galaktozun glikoza parçalanamamasına neden olan, otozomal resesif geçiş gösteren ve nadir görülen kalıtsal bir hastalıktır (Tonguç, 2012). Galaktoz, glukozla 
birlikte süt şekeri olan laktozun monosakkaritlerini oluşturmaktadır. Laktoz vücuda alındıktan sonra ince bağırsaklarda laktaz enzimi aktivitesi ile bu iki monosakkarite parçalanmaktadır. Metabolizmada enerji kaynağı olan asıl monosakkarit glukozdur. Bu nedenle, hücrelere daha fazla enerji sağlayabilmek amacıyla galaktoz etkili bir biçimde glukoza izomerize olmaktadır. Emilen galaktozun \% 90'ı karaciğere gelmekte, galaktokinaz, galaktoz-1fosfat üridil-transferaz ve üridil-galaktoz-4epimeraz enzimlerinin görev aldığı Leloir metabolik yolu ile üç kademede glukoz-1 fosfata çevrilerek hücreler tarafından enerji metabolizmasında kullanılır hale gelmektedir (Kalckar ve ark., 1956; Hasanoğlu ve ark., 1988; Fox ,1997b; Tonguç ve Karagözlü, 2014). İşte metabolizmada bu izomerizasyonu gerçekleştiren başta galaktoz-1-fosfat-üridil-transferaz enzimi olmak üzere üç enzimden herhangi birinin eksikliği, dokularda fazla miktarda galaktoz birikmesine neden olmakta ve bu aşırı galaktoz konsantrasyonu vücutta toksik etki yapmaktadır. $\mathrm{Bu}$ şekilde oluşan rahatsızlığa galaktozemi denmektedir (Slepak ve ark., 2007; Fıçıcıoğlu ve ark., 2008; Tonguç ve Karagözlü, 2014).

Galaktozeminin temel tanı yönteminde, alyuvarlarda galaktoz-1-fosfat-üridil-transferaz aktivitesinin eksikliğinin belirlenmesi ve galaktoz1-fosfatın kırmızı kan hücrelerinde birikiminin tespiti amaçlanmıştır (Ridel ve ark., 2005).

Hastalık resesif genle aileden gelmektedir. Bebeklerde, daha ilk aylarda anne sütü alımı ile ortaya çıkan galaktoz malabsorpsiyonunun en belirgin semptomları kusma ile sık, bol sulu ve asidik ishaldir. Hemen tanı konulmadığı takdirde çocukta ishalle birlikte ciddi bir dehidrasyon gözlemlenmekte ve hastalık ölümcül olabilmektedir. Hastalığın ağır ishal ile seyretmesi nedeniyle tanının gecikmesi durumunda ağır gelişme geriliği ve nöromotor bozukluk görülmektedir. Nöromotor bozuklular ilerleyen durumlarda katarakta yol açabilmektedir (Bülbül ve ark., 2008; Tonguç ve Karagözlü, 2014).

Süt ve süt ürünleri, margarinler veya süt içeren diğer gıda ürünleri, süt tozu, peynir altı ürünleri, kazein ve kazeinatlı ürünler galaktozemi tanısı konmuş bebek ya da çocuğun diyetinden çıkartılmalıdır. Süte alternatif olabilecek formülasyonların diyete eklenmesi gerekmektedir. Bu amaçla soya esaslı mamalar hazırlanmıştır. Soya esaslı özel mama bulunamazsa soya unu kullanılır. Çocuk büyüdükçe, soya ununa pirinç unu ve buğday unu eklenerek çorba ve muhallebi yapılmaktadır. Süt ve laktoz içeren süt ürünleri dışındaki diğer besinler normal şekilde verilmeye devam edilir. Ancak, günlük diyete 300-500 mg kadar kalsiyum sağlayacak kalsiyum tuzları eklenir. Dört yaşından sonra da süt sınırlaması sürdürülür, fakat sınırlama derecesi daha hafiftir. Çocuk, dört yaşından sonra az miktarda da olsa yemeklerin içerisinde süt türevlerinden alabilmektedir. Ayrıca aşırı derecede düşük galaktoz oranına sahip tahıl ürünleri, meyveler, sebzeler ve etler verilmeye başlanabilir. Diyet hastanın hayatı boyunca uygulanmak zorunda olduğu bir süreçtir ve bu süreçte diyette süt ürünü yer almadığında, özellikle yetişkin hastaların kalsiyum desteği almaları gerekmektedir. Galaktosemi tedavi merkezlerinde çalışan ve metabolik hastalıkların tedavisi üzerine eğitim almış diyetisyenler, hastalara ve ailelerine destek vermekte, diyet konusunda yönlendirmekte ve hastalıklarının gelişimini kayıt altına almaktadırlar (Baysal, 1992; Tonguç, 2012; Tonguç ve Karagözlü, 2014).

\section{Früktoz intoleransı}

Früktoz, glukozla birlikte sukrozu oluşturan monosakkarittir. Sukroz diğer adıyla sakkarozdan daha tatlı olan früktoz doğal olarak balda ve meyvelerde bulunmaktadır. Diyetle alınan karbonhidratların yaklaşık $1 / 3^{\prime}$ ü ile $1 / 6^{\prime}$ 'sını früktoz oluşturmaktadır. Früktozun \%50'den fazlası früktoz metabolik yolu ile metabolize edilmektedir. ilk olarak früktoz früktokinaz enzimi früktoz-1-fosfata dönüştürülmektedir. Daha sonra früktoz-1-fosfat, früktoz-1-fosfat aldolaz (1fosfofrüktoaldolaz) enzimiyle gliseraldehit ve dihidroksi aseton fosfata dönüştürülmektedir. Metabolizmada früktoz-1-fosfat aldolaz enzimi kalıtsal nedenlerden dolayı (aldolaz B geninde 
ortaya çıkan mutasyonlar yüzünden) sentezlenemediğinde herediter früktoz intoleransı meydana gelmektedir. Bu enzimin eksikliğinde früktoz-1-fosfat birikmekte ve karaciğer ve böbrek tübülü hücrelerinde toksik etki göstermektedir. Ayrıca früktoz-1-fosfat, fosforilaz enziminin kompetetif inhibitörüdür. Fosforilaz enzimi glikojeni glukoza çeviremez ve hipoglisemi oluşur (Kranhold ve ark., 1969; Guery ve ark., 2007; Anonim, 2008).

Hastalığın ülkemizde gözükme ihtimali yaklaşık $1 / 40.000$ 'dir. Früktoz veya çay şekeri bebek diyetine konulur konulmaz semptomlar ortaya çıkmaktadır. Çocukların memeden kesilmesi sırasında diyete sukrozun yavaş yavaş eklenmesiyle sendromun kronik tablosu oluşur. Erken klinik belirtiler, galaktozemiye benzemektedir. Kilo alamama, kusma, letarji, irritabilite, konvulziyonlar, büyüyememe, sarılık, hepatomegali, ödem, bu belirtilerin başlıcalarıdır. Böbrek tübülülerinin tutulmasına bağlı olarak Fankoni sendromu oluşur. Raşitizm de gelişebilmektedir. Ortaya çıkan semptomlardan biri de irritabil bağırsak sendromudur. Ayrıca mide bulantısı, karın ağrısı, kusma gibi bir takım gastrointestinal rahatsızlıklar da yaygın olarak görülmektedir (Shepherd ve Gibson, 2006; Guery ve ark., 2007).

Hastalığın tanısında kullanılan başlıca yöntemler, früktoz solunum testi, damariçi früktoz tolerans testi ve genetik testtir. $\mathrm{Bu}$ testlerden früktoz solunum testi laktoz solunum testine benzemektedir. Damar içi früktoz tolerans testi ise kandaki früktoz konsantrasyona bağlı olarak ölçülmektedir. Genetik testte ise Aldolaz B geninde aynı anda üç noktadaki mutasyonun analizi yapılabilmektedir. Diğer bir tanı yöntemi ise idrardaki şekerin kromatografi ile früktoz olduğunun gösterilmesidir (Guery ve ark., 2007; Kriegshäuser ve ark., 2007).

Früktozun intoleransının tedavisi diyetten früktoz ve sükroz içeren gıdaların çıkarılmasıyla olmaktadır. Früktozun zengin olduğu pekmez, üzüm, incir, bal gibi yiyecekler ve tatlı olan tüm meyveler diyetten çıkarılır ve hazır mama karışımları kullanılır. Diyet tedavisi hayat boyu sürdürülmelidir. Diyet tedavisi olmazsa beyinde hasar oluşabilir ve çocuklarda ölümle sonuçlanabilir.

\section{Favizm}

Favizm, metabolizmada pentoz-fosfat yolunun ilk basamağını katalizleyen glukoz-6-fosfatdehidrogenaz enziminin eksik olması veya yeterince aktif olamaması durumunda ortaya çıkan bir gıda intoleransıdır. Hastalık baklalarda veya bazı kimyasallarda bulunan oksitleyici maddelerin vücuda alınmasından sonra gerçekleşen oksidasyon sonucu hemoglobinin geri dönüşümsüz bir şekilde denature olmasıyla sonuçlanmaktadır. Hastalığın en önemli semptomu hemoliz olmakla birlikte yorgunluk ve adale ağrıları da en sık rastlanan semptomlar arasındadır.

Glükoz-6-fosfat-dehidrogenaz eksikliği, dünyada en sık rastlanan eritrosit enzim eksikliğidir ve 400 milyondan fazla insanı etkilemektedir. Bu enzim eksikliğinin sıklığı Akdeniz ülkelerinde, Afrika'da ve Çin'de daha yüksek olmakla birlikte bütün ırklarda ve etnik gruplarda tanımlanmıştır. Türkiye genelinde enzim eksikliği \%0,5 olarak saptanmıştır. Dondurulmuş veya kurutulmuş bakla yenmesi ve bakla bitkisinin polenlerinin solunması bile bazı kişilerde hemolize yol açabilmektedir. Favizm oluşumuna özellikle ilkbaharda Akdeniz ülkelerinde rastlanmaktadır. Süt veren annelerin bebeklerinde de hemoliz bildirilmiştir. Yetişkinlere göre çocuklarda daha sık favizm olgusuna rastlanmaktadır (Kuray, 2009; Şaşmaz, 2009).

Diğer gıda intoleranslarında olduğu gibi favizmde de hastalığın erken tanısı oldukça önemlidir. Tanı glukoz-6-fosfat-dehidrogenaz enziminin eksikliğinin belirlenmesi şeklinde yapılmaktadır. Enzim eksikliğini ya da işlevsizliğini tamamen ortadan kaldıracak bir tedavi yöntemi günümüz tıbbında yoktur. Fakat yürütülen genetik araştırmalarda bu hastalığın kesin çaresi bulunmaya çalışılmaktadır. Bu rahatsızlığa sahip olanlar bakla yememeli ve oksitleyici ajanlardan uzak durmalıdır. Oksitleyici (bu rahatsızlığı tetikleyici) maddeler arasında antipiretikler (aspirin vb içeren ateş düşürücü ilaçlar), 
sulfonamid grubu antibiyotikler ve sıtma ilaçları (özellikle kinin) sayılabilmektedir. Bakla ve bakla yapılan tüm ürünler diyetten çıkarılmalıdır (Kuray, 2009).

\section{Sonuç ve Öneriler}

Metabolik gıda intoleransı günümüzde pek çok kişinin karşı karşıya kaldığı bir problemdir. Vücuttaki bir takım enzimlerin eksikliğinden kaynaklanan bu tür rahatsızlıklara karşı farkındalığı artırmak karşılaşılan hastalığın erken tanısında önemli rol oynamaktadır. Ayrıca intolerant bireylerin hastalık hakkında bilgi sahibi olmaları pek çok açıdan büyük önem arz etmektedir. Çünkü bazı besin öğelerini sindiremeyen bireyler gıda intoleransının türüne göre farklılık gösterse de genellikle karın ağrısı, diyare, mide bulantısı, şişkinlik, hazımsızlık, hırıltı, burunda akıntı, baş ağrısı ve kurdeşan gidi rahatsılıklar yaşanmaktadır. $\mathrm{Bu}$ sebeple intolerant bireylerin yaşam kalitesinde ciddi bir azalma meydana gelmekte, yalnızca sağlık durumları değil sosyal hayatları da bu durumdan olumsuz etkilenmektedir. Erken dönemde tanısı konulmayan intoleranslar ilerleyen yaşlarda daha büyük sıkıntılarla karşılaşabilmektedir. Gıda intoleranslarının farklı tanı yöntemleri mevcuttur. Ancak bu rahatsızlıkların tanısı zor olduğu gibi, intolerans gösterilen gıdaların diyetten çıkarılması dışında kesin bir tedavi yöntemi de mevcut değildir. Bu sebeple, intolerant bireylerin uygun bir diyetle beslenmeleri büyük önem arz etmektedir.

Gıda bilimi ve teknolojisinde gıda intoleransı olan kişilerin diyetine yeni ürünler ekleyebilmek amacıyla pek çok çalışma yapılmıştır ve yapılmaya devam etmektedir. Özellikle laktozsuz süt, glutensiz ekmek, bisküvi gibi ürünler piyasada kolaylıkla bulunabilmektedir. Rahatsızlığa sebep olan besin maddelerinin diyetten tamamen uzaklaştırılabilmesi için rahatsızlığı yaşayan bireylerin ve yakınlarının satın aldıkları gıdaların etiket bilgilerini dikkatli okumaları büyük önem taşımaktadır. Söz konusu besin maddelerinden uzak durmak ve alternatif gıdalara yönelmek yaşanabilecek

rahatsızlıkları önlemede başvurulabilecek tek ve en etkili yöntem olarak görülmektedir.

\section{Kaynaklar}

Akarslan, Z., Akdevelioğlu, M., Erten, H., 2007. Çölyak hastalığı vaka raporu ve ağız bulguları ile ilgili literatür derlemesi. Diş Hekimliği Bilimleri Dergisi, 13 (3): 114-120.

Altunsu, T., 2007. Ulusal yenidoğan tarama programı. IX. Uluslararası Katılımlı Beslenme ve Metabolizma Kongresi, 22-25 Ekim, 123-125. İstanbul.

Anonim, 2008. T.C. Milli Eğitim Bakanlığı, Ortaöğretim Projesi. Aile ve Tüketici Bilimleri Beslenme Sorunları, Ankara. http://hbogm.meb.gov.tr Erişim Tarihi:20.02.2017

Anonim,

2017.

http://beslenme.gov.tr/content/files/colyak/brosur. pdf Erişim Tarihi:20.02.2017.

Arslan, G., Ødegaard, S., Elsayed, S., Florvaag, E., Berstad, A., 2002. Food allergy and intolerance: response to intestinal provocation monitored by endosonography. European Journal of Ultrasound, 15: 29-36.

Artan, R., 2005. Çölyak hastalığı. Pediatrik Bilimler Dergisi, 1(8): 60-64.

Ascher, H., 1996. Childhood coeliac disease in Sweden. 1. Baskı, Göteborg, p. 42-43.

Aydoğdu, S., Tümgör, G., 2005. Çölyak hastalığı. Güncel Pediatri, 2: 47-53.

Bayrak, P., 2006. Besin alerjileri. Sağlıkta Birikim, 1(1): 111121.

Baysal, A., 1992. Genel Beslenme. Hatipoğlu Yayınları, Ankara, 196-201.

Book, L., Zone, J.J., Neuhausen, S.L., 2003. Prevalance of celiac disease among relatives of sib pairs with celiac disease in U.S. families. The American Journal of Gastroenterology, 98: 377-81.

Bruijnzeel-Koomen, C., Ortolani, C., Aas, K., Bindslev-Jensen, C., Björkstén, B., Moneret-Vautrin, D., Wüthrich, B. 1995. Position paper of the European Academy of allergology and clinical immunology on adverse reactions to food. Allergy, 12: 357-378.

Bülbül, A., Okan, F., Bülbül, L., Nuhoğlu, A,. 2008. Yenidoğan döneminde glukoz galaktoz malabsorbsiyonu: ìki olgu sunumu. Şişli Etfal Hastanesi Tıp Bülteni, 42(3): 13-16.

Cabrera-Chávez, F. ve Calderón de la Barca, A.M., 2010. Trends in wheat technology and modification of gluten proteins for dietary treatment of coeliac disease patients. Journal of Cereal Science, 52(3): 337-341.

Cummins, A.G., Roberts-Thomson I.C., 2009. Prevalence of celiac disease in the Asia-Pacific region. Journal of Gastroenterol and Hepatology, 24: 1347-1351.

Cunningham, G.H. Day, R. W., Berman, J.L., Hsia D.Y., 1969. In families with phenylketonuria and hyperphenylalaninemia. Am. J. Dis. Child., 117(6): 626-635. 
Dahlqvist, A., Hammond, J.B., Crane, R.K., 1963. Intestinal lactase deficiency and lactose intolerance in adults. Gastroenterology, 45: 488-91.

Dalgic, B., Sari, S. Basturk, B., Ensari, A., Egritas, O., Bukulmez, A., Baris Z. and the Turkish Celiac Study Group., 2011. Prevalence of celiac disease in healthy Turkish school children. The American Journal of Gastroenterology, 106: 1512-1517.

Dede, H., 2016. Çölyakla yaşamak. http://www.saglikvebeslenmebienali.com/pdfler/su numlar/hande-dede.pdf. Erişim tarihi: 10.02.2017

Demirkesen, I.., Mert, B., Sumnu, G., Şahin, S., 2010. Utilization of chestnut flour in gluten-free bread formulations. Journal of Food Engineering, 101: 329336.

Ergin, Aliye., 2011. Çölyak hastalarına özel bisküvi, erişte ve pide üretimi. Yayımlanmamış Yüksek Lisans Tezi, Pamukkale Üniversitesi, Fen Bilimleri Enstitüsü, Denizli.

Ergül, N., 2011. Fenilketonüri hastaları için meyveli puding toz karışımının üretimi. Yüksek Lisans Tezi, Ege Üniversitesi, Fen Bilimleri Enstitüsü, İzmir, 79s.

Fadıloğlu, S., Erkmen O., 2004. Gıda sanayinde enzimlerin önemi. Gıda, 29(5): 393-400.

Ferguson, A., 1992. Definitions and diagnosis of food intolerance and food allergy: Consensus and controversy. The Journal of Pediatrics, 5(2): 7-11.

Fıçıcıoğlu, C., Thomas, N., Yager, C., Gallagher, P.R., Hussa, C., Mattie, A., Day-Salvatore, D.L, Forbes, B.J., 2008. Duarte (DG) galactosemia: A pilot study of biochemical and neurodevelopmental assessment in children detected by newborn screening. Molecular Genetics and Metabolism, 95(4): 206-212.

Fox, P.F., 1997a. Advanced Dairy Chemistry, Volume 3:Lactose, water, salts and vitamins, Chapter 4: Lactose: Nutritional Significance. Chapman \& Hall, 2. Ed., 136-147pp.

Fox, P.F., 1997b. Advanced Dairy Chemistry, Volume 3: Lactose, water, salts and vitamins, Chapter 3: Lactose and enzymatic modification, . Chapman \& Hall, 2. Ed., 77-125pp.

Gallagher, E., 2008. Formulation and nutritional aspects of gluten-free cereal products and infant foods. Glutenfree cereal products and beverages. (Ed) Elke K. Arendt and Fabio Dal Bello, 321-346pp.

Gambus, H., Gambus, F., Pastuszka, D., Wrona, P., Ziobro, R., Sabat, R., Mickowska, B., Nowotna, A., Sikora, M., 2009. Quality of gluten-free supplemented cakes and biscuits. International Journal of Food Properties, 60(S4): 31-50.

Guery, M.J., Douillard, C., Marcelli-Tourvieille, S., Dobbelaere, D., Wemeau, J.L., Vantyghem, M.C., 2007. Doctor, my son is so tired... about a case of hereditary fructose intolerance. Annales d'Endocrinologie, 68(6): 456-459.

Gübür, S., 2012. Besin intoleransı saptanan kilolu ve obez kişilere uygulanan eliminasyon diyetinin, vücut kompozisyonu ve biyokimyasal parametrelere etkisinin belirlenmesi. Yüksek Lisans Tezi, İstanbul Bilim Üniversitesi, Sağlık Bilimleri Enstitüsü, Beslenme ve Diyetetik Yüksek Lisans Programı, İstanbul, 94s.

Hanley, W.B., Platt, L.D., Bachman, R.P., Buist, N., Geraghty,
M.T., Isaacs, J., O’Şynn, M.E., Rhead, W.J., Seidlitz, G., Tishler, B., 1999. Undiagnosed maternal phenylketonuria: The need for prenatal selective screening or case finding. American Journal of Obstetrics and Gynecology, 180(4): 986-994.

Harju, M., 2000. Milk sugar and minerals as ingredients. Int J. of Dairy Tech., 54: 61-63.

Hasanoğlu, A., Kurtoğlu, S., Balkanlı, S., Kendirci, M., 1988. Galaktozemi. Türk Patoloji Dergisi 4(1): 36-40.

Hill, I.D., Bhatnagar, S., Cameron, D.J.S., De Rosa, S., Maki, M., Russell, G., 2002. Celiac disease: Working Group Report of the First World Congress of Pediatric Gastroenterology, Hepatology and Nutrition. J. Pediatr Gastroenterol. Nutr., 35(2): 578-88.

Hill, I.D., Dirks, M.H., Liptak, G.S., 2005. Guideline for the diagnosis and treatment of celiac disease in children: Recommendations of the North American Society for Pediatric Gastroenterology, Hepatology and Nutrition. J. Pediatr Gastroenterol. Nutr., 40: 1-19.

Högberg, L., Magnusson, F.K., Grodzinsky, E., Stenhammar, L., 2003. Familial prevalence of coeliac disease: a twenty- year follow-up study. Scand J. Gastroenterol., 1: 61-65.

Ispano, M., Scibilia, J., Ansaloni, R., Rotondo, F., Vannucci, L., Ortolani, C., 1998. Definition and classification of food allergy and intolerance. Revue Française d'Allergologie et d'Immunologie Clinique, 38(7): 179182.

Johansson, S.G., Hourihane, J.O., Bousquet, J., 2001. Position paper. A revised nomenclature for allergy. An $E A A C l$ position statem from the EAACl nomenclature task force. Allergy, 56: 813-824.

Kalckar, H.M., Anderson E.P., Isselbacher, K.J., 1956. Galactosemia, a congenital defect in a nucleotide transferase. Biochimica et Biopyhsica Acta, 20: 262268.

Kılıç, M., Güneş, G., Boyacıoğlu, D., 2008. Fenilketonüri hastalarına yönelik özel beslenme amaçlı peynir üretimi, TÜBiTAK Proje No: 1060075.

Kranhold, J.F., Loh, D., Morris, C., 1969. Renal fructosemetabolizing enzymes: significance in hereditary fructose intolerance. Science, 165(3891): 402-403.

Kriegshäuser, G., Halsall, D., Rauscher, B., Oberkanins, C., 2007. Semi-automated, reverse-hybridization detection of multiple mutations causing hereditary fructose intolerance. Molecular and Cellular Probes, 21 (3): 226-228.

Levitt, M.D., Donaldson, R.M., 1970. Use of respiratory hydrogen excretion to detect carbonhydrate malabsorption. J. Lab. Clin. Med., 75: 937-945.

Matalon, R., Michals, K., 1991. Phenylketonuria: Screening, treatment and maternal PKU. Clinical Biochemistry, 24 (4): 337-342.

McBean, L.D., Miller, G.D., 1998. Allaying fears and fallacies about lactose intolerance. Journal of the American Dietetic Association, 98(6): 671-676.

Menzel, J., Domschke, W., 2000. Gastrointestinal miniprobe sonography: The current status. Am J. Gastroenterol., 95: 605-616.

Mezaize, S., Chevallier, S., Le Bail, A., De Lamballerie, M., 2009. Optiminization of gluten-free formulations for french-style breads. Journal of Food Science, 74(3): 
140-146.

Moroni, A.V., Bello, F.D., Arendt, E.K., 2009. Sourdough in gluten-free bread-making: An ancient technology to solve a novel issue? Food Microbiology, 26(7): 676684.

Ortolani, C., Pastorella, E.A., 2006. Food allergies and food intolerances. Best Practice \& Research Clinical Gastroenterology, 20(3): 467-483.

Özer, B., 2006. Yoğurt bilimi ve teknolojisi. Harran Üniversitesi, Ziraat Fakültesi, Gıda Mühendisliği. Toprak Ofset, 488s.

Özer, E.A., Banoğlu, G., Banoğlu, E., 2008. Fenilketonüri hastalığı ve fenilalanin kısıtlı diyet. Türkiye 10. Gıda Kongresi, 21-23 Mayıs, 1139-1140, Erzurum.

Özer, M., Tuncel, N.B., 2016. Pirinç ve pirinç yan ürünlerin glutensiz tahıl ürünlerinde kullanılması. Çanakkale 18 Mart Üniversitesi Fen Bilimleri Enstitüsü Dergisi, 2(2):29-44.

Patıroğlu, T.E., 1994. Sindirim kanalı patolojisi. Erciyes Üniversitesi Yayınları, 78: 117-123.

Ray, B., 1996. Fundamental food microbiology. CRC press, Inc., New York. 169-180pp.

Ridel, R.K., Leslie, N.D., Gilbert, D.L., 2005. An updated review of the long-term neurological effects of galactosemia, Pediatric Neurology, 33(3): 153-161.

Schober, T.J., O’Brien, C.M., McCarthy, D., Darnedde, A., Arendt, E.K., 2003. Influence of gluten-free flour mixes and fat powders on the quality of gluten-free biscuits. European Food Research and Technology, 216: 369-376.

Seçkin, Y., 2007. Fenilketonürili çocukların pisko-pedegojik sorunları ve çözümleri, IX. Uluslararası Katılımlı Beslenme ve Metabolizma Kongresi, 22-25 Ekim, İstanbul, 39-43s.

Shepherd, S.J., Gibson, P.R., 2006. Fructose malabsorption and symptoms of irritable bowel syndrome: Guidelines for effective dietary management. Journal of the American Dietetic Association, 106 (10): 16311639.
Slepak, T.I., Tang, M., Slepak V.Z., Lai, K., 2007. Involvement of endoplasmic reticulum stress in a novel classic galactosemia model. Molecular Genetics and Metabolism, 92(1): 78-87.

Soysal, A., $2010 . \quad$ Fenilketonüri. fenilketonuri.blogspot.com.tr/2010/08/fenilketonuri -hastalg-bilinmiyor.html Erişim Tarihi:20.02.2017

Spronsen, F.J., Enns, G.M., 2010. Future treatment strategies in phenylketonuria. Molecular Genetics and Metabolism, 99(1): 90-95.

Şaşmaz, i., 2009. Glukoz-6-fosfat-dehidrogenaz enzim eksikliği. Türk pediatri araştırmaları dergisi, 44: 3538.

Tarakçı, Z., Küçüköner E., 2005. Laktoz, laktoz türevleri ve gıda sanayinde kullanımı. Gıda, 30(4): 261-267.

Tenyyson, C.A., Lewis, S.K., Green, P.H.R., 2009. New and developing therapies for celiac disease. Therapeutic Advances in Gastroenterology, 2(5): 303-309.

Tonguç, i. E., 2012. Laktoz ve galaktoz intoleranslı bireylerin tüketimine yönelik fermente süt ürünlerinin geliştirilmesi ve kalite özelliklerinin belirlenmesi. Doktora tezi, Ege Üniversitesi, Fen Bilimleri Enstitüsü, İzmir, 163s.

Tonguç, İ.E., Karagözlü, C., 2014. Galaktozemi, beslenme ve süt Ürünleri. Akademik Gıda, 12(3): 60-64.

Torbica, A., Hadnadev, M., Dapčević, T., 2010. Rheological, textural and sensory properties of gluten-free bread formulations based on rice and buckwheat flour. Food Hydrocolloids, 24: 626-632.

Vatn, M.H., 1997. Symptoms and manifestations of food intolerance. Environmental Toxicology and Pharmacology, 4: 51-53.

Vernia, P., Di Camillo, M., Marinaro, V., 2001. Lactose malabsorption, irritable bowel syndrome and selfreported milk intolerance. Digestive and Liver Disease, 33 (3): 234-239.

Wilson, J., 2005. Milk intolerance: Lactose intolerance and cow's milk protein allergy. Newborn Infant Nurs Rev., 5(4): 203-207. 